\title{
DIRECT SELLING DALAM USAHA PERASURANSIAN DI INDONESIA PERSPEKTIF HUKUM ISLAM
}

\author{
Seri Utami Ningsih \\ UIN Sunan Kalijaga Yogyakarta \\ Jl. Marsda Adisucipto, Yogyakarta \\ Email: sriutaminingsih1407@gmail.com
}

\begin{abstract}
Insurance companies such as PT. Life Insurance Central Asia Raya, PT. Prudential Life Insurance, PT. Generali Indonesia Life Insurance, PT. Tugu Mandiri Life Insurance, PT. MNC Life Insurance, PT. Asuransi Jiwasraya (Persero), and PT. Sequis Life Life Insurance have marketed one of their insurance products with a direct sales system, or better known as direct selling, which was developed by insurance agents by recruiting insurance agents in a row. This paper explains how the Financial Services Authority (OJK) controls the marketing of insurance businesses and the view of Islamic law on the practice of direct selling in insurance marketing. Based on the type, this research is library research. The results showed that the Supervision of the Financial Services Authority was careless from the principles of legal certainty, professionalism, and openness. This is because Direct Selling was not included in the marketing channels stipulated in the Financial Services Authority Regulation (POJK) Number 23 of 2015 concerning Insurance Products and Marketing of Insurance Products. Based on the POJK, direct selling practiced by insurance companies is illegal. The Financial Services Authority emphasizes direct selling as the development of insurance marketing methods by the insurance agent. In the perspective of Islamic law, based on Sadd al-Dzari ah, although basically direct selling is permitted, but the actions of the insurance agent have great potential to endanger the health of the insurance, and the negligence of the supervision of the Financial Services Authority, the law of this direct selling is haram (forbidden). Therefore, the Financial Services Authority must review the direct selling marketing developed by the insurance agent.
\end{abstract}

Keywords: Direct Selling, Insurance Agent, Supervision of OJK

Abstrak: Tulisan ini bertujuan untuk melihat bagaimana akibat dari luputnya pengawasan Otoritas Jasa Keuangan terhadap sistem penjualan langsung yang dilakukan oleh perusahaan perasuransian perspektif hukum Islam. Perusahaan asuransi seperti PT. Asuransi Jiwa Central Asia Raya, PT. Prudential Life Insurance, PT. Asuransi Jiwa Generali Indonesia, PT. Asuransi Jiwa Tugu Mandiri, PT. MNC Life Insurance, PT. Asuransi Jiwasraya (Persero), dan PT. Asuransi Jiwa Sequis Life telah memasarkan salah satu produk asuransinya dengan sistem penjualan langsung atau yang lebih dikenal dengan direct selling. Direct selling bukan termasuk saluran pemasaran yang ditetapkan dalam Peraturan Otoritas Jasa Keuangan (POJK) Nomor 23 Tahun 2015 tentang Produk Asuransi dan Pemasaran Produk Asuransi. Berdasarkan POJK tersebut, direct selling yang dipraktikkan oleh perusahaan asuransi adalah ilegal. Direct selling dikembangkan oleh agen asuransi dengan merekrut agen asuransi secara berturut-turut. Otoritas Jasa Keuangan menegaskan, direct selling sebagai pengembangan cara pemasaran asuransi. Pengawasan ini lengah dari asas kepastian hukum, profesional, dan keterbukaan. Dalam perspektif hukum Islam, berdasarkan Sadd al-Dzari ah, walaupun pada dasarnya direct selling dibolehkan, tapi karena perbuatan agen asuransi itu berpotensi besar membahayakan kesehatan asuransi, ditambah lengahnya pengawasan Otoritas Jasa Keuangan, maka hukumnya menjadi haram. Oleh sebab itu, Otoritas Jasa Keuangan harus meninjau kembali pemasaran direct selling yang dikembangkan oleh agen asuransi tersebut.

Kata kunci: Direct Selling, Agen Asuransi, Pengawasan OJK

\section{Pendahuluan}

Sektor jasa keuangan mendapat perhatian khusus dalam pengaturan dan pengawasannya oleh undang-undang. Bank Indonesia sebagai bank sentral diamanatkan Undang-undang Nomor 23 Tahun 1999 tentang Bank Indonesia 
sebagaimana yang telah diubah dengan Undangundang Nomor 3 Tahun 2004 (selanjutnya disingkat Undang-undang Bank Indonesia) untuk melakukan pengaturan dan pengawasan terhadap bank secara independen, yang bebas dari campur tangan pemerintah dan pengaruh politik. Fungsi pengaturan dan pengawasan tersebut beralih kepada Otoritas Jasa Keuangan atas amanat pasal 34 Undang-undang Bank Indonesia untuk memisahkan fungsi pengawasan perbankan dari bank sentral ke sebuah badan atau lembaga yang independen di luar bank sentral yang akan dibentuk selambatlambatnya tanggal 31 Desember 2010.

Lembaga pengawasan jasa keuangan mendesak dibentuk karena banyaknya permasalahan lintas sektoral di sektor jasa keuangan yang meliputi tindak moral hazard, ${ }^{1}$ belum optimalnya perlindungan konsumen jasa keuangan, dan terganggunya stabilitas sistem keuangan. Maka, dibentuklah Undang-undang Nomor 21 Tahun 2011 tentang Otoritas Jasa Keuangan (selanjutnya disebut UU Otoritas Jasa Keuangan) telah melahirkan suatu lembaga yang independen yaitu Otoritas Jasa Keuangan. Otoritas Jasa Keuangan sebagai lembaga independen, namun independensinya tidak mutlak. Dalam menjalankan tugasnya, Otoritas Jasa Keuangan melakukan koordinasi dan kerja

${ }^{1}$ Dalam konteks asuransi kesehatan, moral hazard merupakan tindakan seseorang yang memiliki satu polis asuransi kesehatan, namun menggunakan lebih dari satu pelayanan kesehatan, Michael A Morissey, Health Insurance (Washington: AUPHA Press, 2008) dalam artikel Ade Haryana, Moral Hazard dalam Asuransi Kesehatan, hlm. 2. Dalam konteks perbankan, moral hazard merupakan perilaku pihak-pihak yang berkepentingan (stakeholder), misalnya pihak bank (pemegang saham dan manajemen) atau debitur perbankan yang menciptakan insentif untuk memiliki agenda dan tindakan tersembunyi yang berlawanan dengan etika bisnis dan hukum yang berlaku untuk keuntungan dirinya. Luiz A, dkk "Can "Moral Hazard" Explain the Asians Crises? (Tokyo: ADB Institute, 2001) dalam jurnalTaswan Ibrahim dan Ragimun, "Moral Hazard dan Pencegahannya pada Industri Perbankan di Indonesia", hlm. 5. Moral hazard merupakan tindakan stakeholder dalam menurunkan atau meningkatkan risiko yang berlawanan dengan etika bisnis dan hukum. sama dengan Bank Indonesia, Badan Pemeriksa Keuangan, ${ }^{2}$ Lembaga Penjamin Simpanan, ${ }^{3}$ dan Menteri Keuangan. Hal tersebut bertujuan agar kebijakan-kebijakan yang dikeluarkan nantinya dapat efektif dan efisien dalam menangani permasalahan di sektor jasa keuangan.

Lembaga pengawasan jasa keuangan (supervisory board) atau Otoritas Jasa Keuangan yang dibentuk tersebut kewenangannya tidak terbatas mengawasi bidang perbankan saja, tetapi juga mengawasi perubahan-perubahan sektor jasa keuangan lainnya yang meliputi asuransi, dana pensiun, sekuritas, modal ventura, dan perusahaan pembiayaan, serta badan-badan lain yang menyelenggarakan pengelolaan dana masyarakat. ${ }^{4}$

Pengaturan dan pengawasan Otoritas Jasa Keuangan terhadap usaha perasuransian di Indonesia mendorong tingkat persaingan yang tinggi antar perusahaan. Otoritas Jasa Keuangan memberikan apresiasi terhadap perusahaan asuransi yang menyampaikan laporan keuangan tercepat, serta penghargaan terhadap perusahaan asuransi yang mengembangkan usaha asuransi mikro. ${ }^{5}$ Kecepatan pelaporan keuangan perusahaan merupakan salah satu unsur kesehatan perusahaan asuransi. Selain itu,

\footnotetext{
${ }^{2}$ Badan Pemeriksa Keuangan adalah lembaga negara yang bertugas memeriksa pengelolaan dan tanggung jawab keuangan negara sebagaimana dimaksud dalam Undangundang Dasar Negara Republik Indonesia Tahun 1945. Lihat Undang-undang Nomor 15 Tahun 2006 tentang Badan Pemeriksa Keuangan, pasal 1.

${ }^{3}$ Lembaga Penjamin Simpanan (LPS) adalah lembaga penjaminan simpanan nasabah dibank dan melakukan penyelesaian atau penanganan Bank Gagal. LPS berfungsi menciptakan dan memelihara stabilitas sistem keuangan bersama dengan Menteri Keuangan, Bank Indonesia, dan Lembaga Pengawas Perbankan, sesuai dengan peran dan tugas masing-masing. Lihat Undang-undang Nomor 24 Tahun 2004 tentang Lembaga Penjamin Simpanan, penjelasan umum dan penjelasan pasal 4.

4 Muhammad Djumhana, Hukum Perbankan di Indonesia (Bandung: Citra Aditya Bakti, 2006), h. 132.

5 Asuransi mikro adalah produk asuransi yang diperuntukkan bagi masyarakat yang berpenghasilan rendah sehingga bisa menikmati manfaat asuransi dalam memberikan santunan.
} 
laporan keuangan menunjukkan peningkatan aset dan pendapatan premi suatu perusahaan asuransi yang menjadi dorongan kuat bagi perusahaan dalam bersaing.

Kesadaran masyarakat yang semakin meningkat merupakan kesempatan perusahaan asuransi dalam memasarkan produknya. Kondisi ini juga menjadi motivasi perusahaan untuk memenangkan persaingan. Ada tiga usaha perusahaan perasuransian dalam memenangkan persaingan. Pertama, mendirikan cabang pemasaran dan pelayanan nasabah di seluruh Indonesia. Kedua, membentuk produk asuransi baru. Ketiga, memaksimalkan sistem pemasaran dengan meningkatkan kerjasama dengan bank dan selain bank, serta pelatihan agen.

Pasal 45 ayat (1) Peraturan Otoritas Jasa Keuangan (POJK) Nomor 23 Tahun 2015 tentang Produk Asuransi dan Pemasaran Produk Asuransi mengatur pemasaran produk asuransi hanya dapat dipasarkan melalui empat saluran, yaitu secara langsung (direct marketing), agen asuransi, bancassurance, dan badan usaha selain bank. Untuk produk asuransi mikro, dapat dipasarkan melalui empat saluran diatas dan tenaga pemasar. Tenaga pemasar dapat berupa komunitas, pegawai koperasi usaha tani, dan lain-lain.

Beberapa perusahaan asuransi memasarkan produk asuransi melalui agen asuransi yang menerapkan sistem direct selling, yaitu perekrutan agen asuransi secara networking (berjenjang) dengan menawarkan bonus terhadap agen sponsor. Agen sponsor disebut juga agen asuransi yang mensponsori agen asuransi setelahnya dalam membeli polis asuransi serta menjalankan usaha penjualan asuransi secara networking. Artinya, sistem direct selling terselubung dalam praktik agen asuransi. Hal ini menyebabkan praktik direct selling tidak terdeteksi dalam pengawasan Otoritas Jasa Keuangan bahwa ada saluran pemasaran yang berkembang dalam saluran pemasaran.

Praktik pemasaran yang berjalan ilegal serta melanggar ketentuan saluran pemasaran produk asuransi akan berdampak negatif pada nasabah, yaitu anggota agen asuransi networking. Pemasaran tanpa adanya kepastian hukum yang melindungi agen asuransi networking dari kejahatan keuangan dalam strategi memenangkan persiangan. Dalam hukum Islam, kepastian hukum merupakan batasan-batasan perbuatan dalam bertindak. Firman Allah swt:

$$
\text { تلك حدود الله فلا تقربوها }
$$

"Itulah larangan Allah, maka janganlah kamu mendekatinya”. (Al-Baqarah (2): 187).

Ayat di atas menunjukkan batasan-batasan perbuatan berupa tidak boleh mendekati dan melanggar ketetapan hukum. Pemasaran direct selling tanpa kepastian hukum berarti tidak memberikan batasan-batasan yang tidak boleh didekati atau dilanggar oleh perusahaan asuransi atau pun agen asuransi networking. Agen asuransi networking yang menjalankan program pemasaran direct selling yang dicetuskan oleh perusahaan asuransi berisiko dengan kejahatan keuangan.

Tulisan ini membahas tentang akibat lengahnya pengawasan Otoritas Jasa Keuangan dalam sistem pemasaran direct selling produk asuransi. Otoritas Jasa Keuangan yang tetap membiarkan sistem pemasaran direct selling berjalan akan menimbulkan risiko bagi persaingan usaha perusuransian.

Tulisan ini menjelaskan Bagaimana pengawasan Otoritas Jasa Keuangan terhadap pemasaran usaha perasuransian? Bagaimana pandangan hukum Islam terhadap praktik direct selling dalam pemasaran asuransi?

Berdasarkan jenisnya, Penelitian ini merupakan penelitian pustaka (library research). Penyusun melakukan penelitian terhadap sumber-sumber data yang berasal dari bahanbahan tertulis berupa regulasi, jurnal, tugas akhir, buku, dan bahan-bahan tertulis lainnya yang mempunyai relasi dengan penelitian ini. 
Data-data penelitian yang telah terkumpul akan dikelolah dengan metode kualitatif, dan dianalisis secara deskriptif.

\section{Agen Asuransi sebagai Subjek Pemasaran Direct Selling}

Pasal 45 ayat (1) Peraturan Otoritas Jasa Keuangan (POJK) Nomor 23 Tahun 2015 tentang Produk Asuransi dan Pemasaran Produk Asuransi mengatur pemasaran produk asuransi hanya dapat dipasarkan melalui empat saluran, yaitu secara langsung (direct marketing), agen asuransi, bancassurance, dan badan usaha selain bank. Untuk produk asuransi mikro, dapat dipasarkan melalui empat saluran diatas dan tenaga pemasar. Tenaga pemasar dapat berupa komunitas, pegawai koperasi usaha tani, dan lain-lain.

Produk asuransi hanya dapat dipasarkan melalui empat saluran pemasaran di atas. Kata 'hanya dapat' menunjukkan bahwa produk asuransi tidak boleh dipasarkan selain empat saluran pemasaran yang telah ditetapkan dalam POJK. Praktik pemasaran direct selling yang dilakukan oleh agen beberapa perusahaan asuransi merupakan saluran pemasaran yang tidak ditetapkan dalam POJK. Beberapa perusahaan asuransi memasarkan produk asuransinya melalui agen asuransi dengan sistem direct selling. Berdasarkan ketetapan saluran pemasaran produk asuransi yang ditetapkan POJK, directselling tidak termasuk empat saluran pemasaran. Agen asuransi dan direct selling merupakan cara memasarkan suatu produk usaha. jadi, praktik saluran pemasaran asuransi ini merupakan saluran pemasaran ganda.

Praktik pemasaran ganda tersebut dijalankan oleh beberapa perusahaan asuransi seperti PT. Asuransi Jiwa Central Asia Raya, PT. Prudential Life Insurance, PT. Asuransi Jiwa Generali Indonesia, PT. Asuransi Jiwa Tugu Mandiri, PT. MNC Life Insurance, PT. Asuransi Jiwasraya (Persero), dan PT.
Asuransi Jiwa Sequis Life. ${ }^{6}$ Direct selling adalah. Menurut Asosiasi Penjualan Langsung Indonesia (APLI), ${ }^{7}$ direct selling adalah metode penjualan barang dan/atau jasa tertentu kepada konsumen dengan cara tatap muka di luar lokasi eceran tetap oleh jaringan pemasaran yang dikembangkan oleh Mitra Usaha ${ }^{8}$ dan bekerja berdasarkan komisi penjualan, bonus penjualan dan iuran keanggotaan yang wajar. ${ }^{9}$

APLI membagi direct selling menjadi dua jenis. Pertama, single level marketing (pemasaran satu tingkat) adalah metode pemasaran barang dan/atau jasa dari sistem Penjualan Langsung melalui program pemasaran berbentuk satu tingkat, dimana Mitra Usaha mendapatkan komisi penjualan dan bonus penjualan dari hasil penjualan barang dan/atau jasa yang dilakukannya sendiri. ${ }^{10}$ Kedua, multi level marketing (pemasaran multi tingkat) adalah metode

\footnotetext{
${ }^{6}$ Perusahaan asuransi yang memasarkan salah satu produk asuransi melalui agen asuransi dengan sistem direct selling tersebut yang diketahui penulis saja, mungkin ada perusahaan asuransi selain itu yang menerapkan sistem yang sama tapi tidak disebutkan oleh penulis. Penulis mengambil daftar perusahaan asuransi yang terdaftar dan diawasi oleh Otoritas Jasa Keuangan. Ada beberapa perusahaan asuransi yang menerapkan sistem direct selling, namun belum terdaftar pada Otoritas Jasa Keuangan. jadi, penulis tidak mencantumkannya.

Asosiasi Penjualan Langsung Indonesia (APLI) dicetuskan oleh Bapak Eddy Budhiman pada tahun 24 Juli 1984. APLI adalah suatu organisasi yang merupakan wadah persatuan dan kesatuan tempat berhimpun para perusahaan penjualan langsung (direct selling/DS), termasuk perusahaan yang menjalankan penjualan dengan system berjenjang (multi level marketing/MLM) di Indonesia. https://www.apli. or.id/profil/ diakses tanggal 10 Mei 2019, pukul 15.22 WIB.

${ }^{8}$ Mitra Usaha adalah anggota mandiri jaringan pemasaran atau penjualan berbentuk badan usaha atau perorangan dan bukan merupakan bagian dari struktur organisasi perusahaan yang memasarkan atau menjual barang dan/atau jasa kepada konsumen akhir secara langsung dengan mendapatkan imbalan berupa komisi dan/atau bonus atas penjualan. Lihat Peraturan Menteri Perdagangan Nomor 32 Tahun 2008 tentang Penyelenggaraan Kegiatan Usaha dengan Sistem Penjualan Langsung, pasal 1 ayat (1) nomor 4.

${ }_{9}^{9}$ https://www.apli.or.id/direct-selling/ diakses tanggal 9 Mei 2019, pukul 10.00 WIB.

${ }^{10} \mathrm{https} / /$ www.apli.or.id/direct-selling/ diakses tanggal 9 Mei 2019, pukul 10.00 WIB.
} 
pemasaran barang dan/atau jasa dari sistem penjualan langsung melalui program pemasaran berbentuk lebih dari satu tingkat, dimana mitra usaha mendapatkan komisi penjualan dan bonus penjualan dari hasil penjualan barang dan/atau jasa yang dilakukannya sendiri dan anggota jaringan di dalam kelompoknya. ${ }^{11}$

Dalam peraturan perundang-undangan Indonesia, direct selling disebut dengan penjualan langsung, sedangkan Dewan Syariah Nasional $^{12}$ Majelis Ulama Indoensia ${ }^{13}$ (DSNMUI) menyebut direct selling dengan penjualan langsung berjenjang. ${ }^{14}$ Dalam Permendag, penjualan langsung adalah metode penjualan barang dan/atau jasa tertentu melalui jaringan pemasaran yang dikembangkan oleh mitra usaha yang bekerja atas dasar komisi dan/atau bonus berdasarkan hasil penjualan kepada konsumen di luar lokasi eceran tetap. ${ }^{15}$ Sedangkan perspektif Dewan Syariah Nasional Majelis Ulama Indonesia (DSN-MUI), penjualan langsung berjenjang adalah penjualan barang atau jasa melalui jaringan pemasaran yang dilakukan oleh perorangan atau badan usaha

${ }^{11}$ https://www.apli.or.id/direct-selling/ diakses tanggal 9 Mei 2019, pukul 10.00 WIB.

${ }^{12}$ Dewan Syariah Nasional (DSN) merupakan lembaga Majelis Ulama Indonesia (MUI) yang bertugas mengeluarkan fatwa untuk dijadikan pedoman dalam kegiatan traksaksi pada lembaga kuangan syariah. Lembaga ini dibentuk pada tahun 2000 terkait dengan perkembangan ekonomi syariah di Indonesia sejak tahun 1992. Lihat Yeni Slam Barlinti, Kedudukan Fatwa Dewan Syariah Nasional dalam Sistem Hukum Nasional di Indonesia (Jakarta: Badan Litbang dan Diklat Kementerian Agama RI, 2010, h. 8.

${ }^{13}$ Majelis Ulama Indonesia (MUI) merupakan tempat bermusyawarah para, zu'ama, dan cendikiawan muslim yang tertuang dalam sebuah "Piagam Berdirinya MUI" pada tanggal 26 Juli 1975. MUI memiliki peran dalam perkembangan hukum di Indonesia, khususnya hukum Islam antara lain melalui fatwa-fatwanya. Yeni Slam Barlinti, Kedudukan Fatwa..., h. 6.

${ }^{14}$ Seri Utami Ningsih, "Asuransi Berbasis Penjualan Langsung Menurut Hukum Islam dan Hukum Positif (Studi Kasus PT. Asuransi Jiwa Central Asia Raya)", Skripsi UIN Sunan Kalijaga Yogyakarta, 2018, h. 43.

15 Peraturan Menteri Perdagangan Nomor 32 Tahun 2008 tentang Penyelenggaraan Kegiatan Usaha dengan Sistem Penjualan Langsung, pasal 1 ayat (1). kepada sejumlah perorangan atau badan usaha lainnya secara berturut-turut. ${ }^{16}$

Istilah penjualan langsung yang digunakan perundang-undangan Indonesia, dalam Peraturan Menteri Perdagangan (Permendag) Nomor 32 Tahun 2008 mengatur pemasaran direct selling single level marketing dan multi level marketing. Sedangkan istilah penjualan langsung berjenjang yang digunakan oleh DSNMUI menunjukkan pemasaran direct selling multi level marketing saja. Kata 'berjenjang' merupakan interpretasi dari pemasaran penjualan langsung lebih dari satu tingkat.

Direct selling dalam asuransi dikembangkan oleh agen asuransi yang notabene merupakan saluran pemasaran. Skema agen asuransi dan mitra usaha direct selling bukan merupakan bagian dari organisasi perusahaan. Sehingga, agen asuransi dan mitra usaha direct selling terlepas dari perusahaan. Dua jenis saluran pemasaran, yaitu agen asuransi dan direct selling yang dipraktikkan oleh perusahaan asuransi penulis sebut dengan 'agen asuransi networking', yaitu agen asuransi memasarkan salah satu produk asuransi kepada calon agen asuransi secara berturut-turut sehingga membentuk jaringan (networking). Dengan demikian, pemasaran direct selling salah satu produk perusahaan asuransi terselubung dalam agen asuransi.

Menurut Word Federation of Direct Selling Associations (WFDSA), asuransi dapat dipasarkan melalui direct selling. Companies market all types of goods and services, including jewelry, cookware, nutritionals, cosmetics, housewares, energy and insurance, and much more. ${ }^{17}$ WFDSA hanya menyebutkan beberapa contoh produk yang dapat dipasarkan melalui direct selling, salah satunya yaitu asuransi. Namun,

${ }^{16}$ Fatwa Dewan Syariah Nasional Majelis Ulama Indonesia Nomor 75 Tahun 2009 tentang Pedoman Penjualan Langsung Berjenjang Syariah. Ketentuan Umum ke-1.

${ }^{17}$ https://wfdsa.org/about-direct-selling/ diakses pada tanggal 10 Mei 2019, pukul 15.08 WIB. 
WFDSA tidak menjelaskan lebih lanjut sistem direct selling produk asuransi. APLI yang merupakan anggota dari WFDSA tidak dapat memasarkan asuransi karena pemasaran asuransi hanya dapat disalurkan berdasarkan POJK Nomor 23 Tahun 2015.

\section{Pengawasan Otoritas Jasa Keuangan terhadap Agen Asuransi}

Otoritas Jasa Keuangan merupakan lembaga yang berwenang untuk mengatur dan mengawasi usaha perasuransian. Pengaturan usaha perasuransian dilakukan dalam bentuk menetapkan peraturan yang wajib dipatuhi dalam melaksanakan kegiatan usaha asuransi yang ditetapkan dalam POJK. Tujuan pengaturan tersebut adalah agar terselenggaranya usaha asuransi secara teratur, adil, transparan, dan akuntabel, mewujudkan sistem keuangan yang tumbuh berkelanjutan dan stabil, serta melindungi kepentingan konsumen dan masyarakat. Peraturan Otoritas Jasa Keuangan tentang usaha perasuransian antara lain terkait dengan perizinan usaha dan kelembagaan perusahaan asuransi, produk dan pemasaran asuransi, tata kelola perusahaan, kesehatan keuangan, risiko asuransi, sanksi administratif, seta pembubaran, likuidasi, dan kepailitan perusahaan asuransi. Peraturan tersebut ditetapkan dengan memperhatikan perundang-undangan secara hierarki di atasnya, yaitu Undang-undang, Peraturan Pemerintah, Peraturan/Keputusan Menteri, dan Peraturan Bapepam.

Pengawasan terhadap usaha perasuransian dilakukan melalui pemeriksaan langsung dan tidak langsung. Pemeriksaan langsung (on site supervision) merupakan rangkaian kegiatan mencari, mengumpulkan, mengolah, dan mengevaluasi data dan/atau keterangan mengenai usaha asuransi yang dilakukan di perusahaan asuransi dan di tempat lain yang terkait langsung maupun tidak langsung dengan kegiatan perasuransian. ${ }^{18}$ Pemeriksaan langsung terdiri dari pemeriksaaan umum dan khusus.

Pemeriksaan umum meliputi pemantauan secara langsung secara berkala meliputi aktifitas-aktifitas perusahaan asuransi, kepatuhan terhadap peraturan, serta menguji laporan-laporan yang telah disampaikan kepada Otoritas Jasa Keuangan. Pemeriksaan khusus fokus pada pengawasan aset, premi, dan produk yang berpotensi membahayakan kesehatan asuransi. Pemeriksaan tidak langsung (off site supervision) merupakan pengawasan yang dilakukan Otoritas Jasa Keuangan melalui laporan keuangan berkala dan laporan tahunan perusahaan asuransi yang harus disampaikan sesuai dengan waktu yang ditentukan.

Tujuan pemeriksaan langsung adalah untuk melihat kondisi usaha perasuransian dan menilai kepatuhan perusahaan asuransi terhadap POJK di bidang asuransi. Saluran pemasaran produk asuransi sebagaimana yang telah dijelaskan pada pembahasan sebelumnya, merupakan ketidakpatuhan perusahaan asuransi terhadap POJK. Otoritas Jasa Keuangan hanya memantau saluran pemasaran agen asuransi yang harus memenuhi persyaratan sebagai agen asuransi, yaitu memiliki sertifikasi keagenan dan keagenan khusus unit link pada agen asuransi yang memasarkan produk unit link.

Setiap perusahaan asuransi yang memasarkan produk melalui direct selling memiliki nama program sendiri yang berbeda. Misalnya, program 31-Network pada Asuransi Jiwa Central Asia Raya merupakan program dalam saluran pemasaran agen asuransi. Otoritas Jasa Keuangan berpendapat bahwa program tersebut merupakan bagian dari program agen asuransi. Pengembangan program pemasaran 3i-Network

18 Dikuotasi dari Peraturan Otoritas Jasa Keuangan Nomor 63 Tahun 2016 tentang Perubahan atas Peraturan Otoritas Jasa Keuangan Nomor 11/POJK.05/2014 tentang Pemeriksaan Langsung Lembaga Jasa Keuangan Non-Bank, pasal 1 ayat (2). 
harus memenuhi peraturan perasuransian tentang agen asuransi. ${ }^{19}$ Jadi, Otoritas Jasa Keuangan tidak melihat pemasaran direct selling yang dijalankan agen asuransi melalui program tersebut karena terselebung dalam pemasaran agen asuransi.

Pengawasan Otoritas Jasa Keuangan lengah atas pemeriksaan langsung dalam meneliti dokumen, observasi kegiatan pendidikan agen asuransi networking, serta keterangan yang sesungguhnya mengenai program agen asuransi. Program pemasaran agen asuransi merupakan pelanggaran terhadap peraturan tentang saluran pemasaran produk asuransi. Sehingga, Otoritas Jasa Keuangan seharusnya memberikan sanksi pembatasan kegiatan usaha dalam pemasaran produk asuransi melalui agen asuransi.

\section{Lengahnya Pengawasan Otoritas Jasa Keuangan terhadap Direct Selling dalam Usaha Perasuransian Perspektif Hukum Islam}

Saluran pemasaran ganda, yaitu agen asuransi yang mengembangkan jaringan direct selling atau program direct selling terselebung dalam saluran pemasaran agen asuransi merupakan kegiatan usaha perasuransian yang melanggar ketetapan Peraturan Otoritas Jasa Keuangan tentang Produk Asuransi dan Pemasaran Produk Asuransi. Direct selling merupakan sistem pemasaran di luar peraturan tersebut. Otoritas Jasa Keuangan hanya meneliti kepatuhan dalam menentukan seseorang untuk menjadi agen asuransi, tanpa menelaah lebih lanjut tentang program networking yang berkembang. Agen asuransi yang merupakan karyawan lepas dari perusahaan tetap harus patuh terhadap peraturan yang ditetapkan oleh Otoritas Jasa Keuangan.

Lengahnya pengawasan Otoritas Jasa Keuangan dapat dilihat dari tidak teliti dalam memeriksa dokumen maupun berkas

19 E-mail Direktorat Pelayanan Konsumen Otoritas Jasa Keuangan Kepada Seri Utami Ningsih, 5 Februari 2018. yang berkaitan dengan program pemasaran agen asuransi, kegiatan pelatihan dan/atau motivasi agen asuransi dalam merekrut agen asuransi berturut-turut, keterangan-keterangan lainnya yang berkaitan dengan program agen asuransi lebih lanjut. Bahkan, Otoritas Jasa Keuangan menegaskan bahwa pemasaran produk melalui direct selling merupakan pengembangan yang dilakukan perusahaan asuransi dari segi cara pemasaran. ${ }^{20}$ Kalau pun direct selling merupakan pengembangan cara pemasaran produk asuransi, praktik tersebut harus mendapat Surat Izin Usaha Penjualan Langsung (SIUPL) sesuai dengan ketentuan Peraturan Menteri Perdagangan Nomor 32 Tahun 2008 tentang Penyelenggaraan Kegiatan Usaha Perdagangan dengan Sistem Penjualan Langsung. ${ }^{21}$ Tapi, praktik direct selling beberapa perusahaan asuransi tidak mempunyai surat izin tersebut. Perusahaan asuransi hanya menjamin prosedural menjadi agen asuransi.

Otoritas Jasa Keuangan melaksanakan tugas dan wewenangnya berlandaskan asas independensi, kepastian hukum, kepentingan umum, keterbukaan, profesionalisme, integritas, dan akuntabilitas. ${ }^{22}$ Asas kepastian hukum pengawasan Otoritas Jasa Keuangan terhadap perkembangan pemasaran produk asuransi merujuk pada pasal 45 ayat (1) POJK Nomor 23 Tahun 2015 bahwa produk asuransi hanya dapat dipasarkan secara langsung (direct marketing), agen asuransi, bancassurance, dan badan usaha selain bank. Otoritas Jasa Keuangan menegaskan bahwa direct selling merupakan pengembangan saluran pemasaran menunjukkan bahwa pengawasan Otoritas Jasa Keuangan lalai terhadap asas kepastian hukum tersebut. Tidak hanya

${ }^{20}$ E-mail Direktorat Pelayanan Konsumen Otoritas Jasa Keuangan kepada Anto Cahaya, 22 Desember 2015.

${ }^{21}$ Setiap perusahaan (penjualan langsung) wajib memiliki SIUPL. Peraturan Menteri Perdagangan Nomor 32 Tahun 2008 tentang Penyelenggaraan Kegiatan Usaha Perdagangan dengan Sistem Penjualan Langsung, pasal 9 ayat (1).

22 Penjelasan umum Undang-undang Nomor 21 Tahun 2011 tentang Otoritas Jasa Keuangan. 
itu, Otoritas Jasa Keuangan juga lalai dengan landasan asas profesionalitas pengawasan yang harus teliti terhadap praktik pemasaran dengan keahlian yang mengutamakan peraturan perundang-undangan.

Pengembangan saluran pemasaran produk asuransi yang dilakukan perusahaan asuransi yang tidak termasuk dalam POJK menjelaskan bahwa direct selling tidak mendapat pengawasan dari Otoritas Jasa Keuangan. Direct selling diselenggarakan bertujuan untuk meningkatkan premi dan aset perusahaan asuransi dalam memenangkan persaingan. Cara yang melanggar POJK merupakan persaingan yang tidak sehat. Ketidaksehatan perusahaan ditunjukkan pada ketidakkepatuhan terhadap peraturan perundang-undangan. Perusahaan yang tidak sehat berpotensi melakukan kejahatan keuangan, terutama mengancam penyalahgunaan premi agen asuransi networking.

Dalam ajaran Islam, tujuan disyariatkannya hukum Islam adalah untuk mewujudkan mashlahat dan menolak mudarat. Mashlahat yang akan diwujudkan itu berguna untuk memelihara 5 perkara pokok yaitu agama, jiwa, akal, keturunan/kehormatan,dan harta. Dalam realisasinya, pemeliharaan 5 perkara pokok tersebut harus memperhatikan skala prioritas dalam penggunaannya pada tiga tingkatan, yaitu dharuri (primer), hajiy (sekunder), dan tahsiniy (tersier). ${ }^{23}$ Oleh sebab itu, perbuatan mashlahat yang dilakukan tidak boleh mendatangkan kerusakan. Sebelum sampai pada pelaksanaan perbuatan yang dituju itu, ada serentetan pertimbangan dan perbuatan yang mendahuluinya yang harus dilalui. ${ }^{24}$ Dalam kajian Ushul Fiqh, perbuatan yang menjadi perantara kepada suatu tujuan disebut sadd aldzariah.

23 Toha Andiko, Suansar Khatib, Romi Adetio Setiawan, Maqashid Syariah dalam Ekonomi Islam, (Yogyakarta: Samudra Biru, 2018), h. 59-60.

${ }^{24}$ Amir Syarifuddin, Ushul Fiqh 2, (Jakarta: Kencana, 2008), h. 447.
Secara etimologi, kata sadd berarti menutup. ${ }^{25}$ Sedang al-dzari ah ialah apa-apa yang menjadi perantara dan jalan kepada sesuatu. Adapun menurut istilah Ushûl al-Fiqh, sadd al-dzari' ah ialah sarana atau jalan untuk sampai pada tujuan. Dan tujuan yang dimaksud ada kalanya perbuatan-perbuatan taat, dan ada kalanya pula perbuatan-perbuatan maksiat. Perbuatan taat berarti mashlahah, sedang perbuatan maksiat berarti mafsadah. Sesuatu yang menjadi sarana kepada yang diharamkan (membawa mafsadah/ kerusakan), maka sarana tersebut harus ditutup dan dicegah, dan inilah yang disebut dengan sadd al-dzarî ah. ${ }^{26}$ Dengan demikian, menurut Imam Al-Syatibi, sadd al-dzariah adalah menutup jalan/melakukan sesuatu pekerjaan yang semula kemaslahatan untuk menuju suatu kemafsadatan. $^{27}$

Jadi sadd al-dzari'ah mengandung makna bahwa walaupun syara' tidak menetapkan hukum suatu perbuatan secara jelas, namun karena perbuatan itu diyakini sebagai washîlah (sarana) bagi perbuatan yang dilarang atau menimbulkan mafsadat, maka hal itu menjadi petunjuk bahwa hukum washîlah itu adalah seperti hukum terhadap perbuatan atau akibat yang ditimbulkannya. Ada perbuatan yang sebenarnya hukumnya mubah, tapi jika berpotensi menimbulkan bahaya, maka perbuatan tersebut menjadi dilarang. Misalnya menghentakkan kaki pada dasarnya boleh bagi laki-laki dan perempuan. Tapi bagi perempuan jika menghentakkan kakinya akan menyebabkan perhiasannya yang tersembunyi dapat diketahui laki-laki lain sehingga akan menimbulkan rangsangan bagi yang mendengarnya, maka menghentakkan kaki itu

25 Lihat Ahmad Warson Munawwir, Al-Munawwir: Kamus Arab Indonesia, (Surabaya: Penerbit Pustaka Progressif, 1997), h. 620.

26 Wahbah al-Zuhaili, al-Wasîth fi Ushûl al-Fiqh alIslâmi, (Damaskus: Dâr al-Kitâb, 1978), h. 873-874.

27 Abdul Aziz Dahlan, Ensiklopedi Hukum Islam, (Jakarta: Ichtiar Baru van Hoeve, 1996), Jilid 6, h. 920. 
menjadi terlarang bagi perempuan. ${ }^{28}$

Sejalan dengan analogi contoh di atas, pengembangan cara pemasaran produk asuransi melalui direct selling pada dasarnya dibolehkan, tapi jika lengah oleh pengawasan Otoritas Jasa Keuangan, akan mengakibatkan kejahatan keuangan, terutama premi agen asuransi yang tidak terlindungi. Pengawasan Otoritas Jasa Keuangan merupakan perbuatan yang menjadi perantara terjadinya kerusakan, yaitu kejahatan keuangan. Dalam menjaga kehatihatian, Otoritas Jasa Keuangan harus meninjau kembali pengembangan pemasaran yang dilakukan perusahaan asuransi dari segi peraturan perundang-undangan dan risiko yang akan dihadapi jika direct selling tersebut terus berkembang. Prinsip yang sesuai dengan kaidah

$$
\text { درء المفاسد مقدم على جلب المصالح }
$$

"Menolak kerusakan diutamakan ketimbang mengambil kemaslahatan".

Perusahaan asuransi yang sehat bergantung pada pengawasan Otoritas Jasa Keuangan sesuai dengan latar belakang terbentuknya lembaga pengawasan sektor jasa keuangan ini. Sehingga, lengahnya pengawasan Otoritas Jasa Keuangan membahayakan tingkat kesehatan perusahaan asuransi.

\section{Penutup}

Kesadaran masyarakat teehadap pentingnya asuransi semakin meningkat dari tahun ke tahun. Hal ini merupakan kesempatan bagi perusahaan asuransi dalam memasarkan produknya. Persaingan asuransi dalam mendapatkan nasabah membuat beberapa perusahaan mengembangkan cara pemasaran, diantaranya direct selling. Pemasaran direct selling dikembangkan oleh agen asuransi yang notabene cara pemasaran produk asuransi.

${ }^{28}$ Toha Andiko, "Larangan Bercadar di Perguruan Tinggi Perspektif Sadd al-Dzarî̀ah”, Madania, Vol. 22, No. 1, 2018, h. 124-125.
Agen asuransi merekrut agen selanjutnya secara berturut-turut dengan imbalan komisi sesuai dengan usaha yang dilakukannya.

Otoritas Jasa Keuangan sebagai lembaga yang bertugas mengawasi aktifitas usaha perasuransian menganggap bahwa direct selling merupakan pengembangan cara pemasaran yang dilakukan oleh agen asuransi. Adapun agen asuransi tetap harus mengikuti prosedural sebagai agen asuransi. Otoritas Jasa Keuangan berpendapat bahwa direct selling merupakan bagian dari agen asuransi. Padahal, direct selling merupakan cara pemasaran ilegal yang diselebungkan melalui agen asuransi. Direct selling merupakan sistem pemasaran yang harus memiliki Surat Izin Usaha Penjualan Langsung (SIUPL) dari Menteri Perdagangan. Agen asuransi dan mitra usaha penjualan langsung melewati prosedur yang berbeda untuk bisa memasarkan produk perusahaan, serta berada dalam pengawasan lembaga yang berbeda pula.

Pengawasan Otoritas Jasa Keuangan lengah dalam mengawasi cara pemasaran direct selling secara profesional dan kepastian hukum yang telah diatur dalam Peraturan Otoritas Jasa Keuangan (POJK) Nomor 23 Tahun 2015 tentang Produk Asuransi dan Pemasaran Produk Asuransi, pasal 45 ayat (1). Dalam POJK tersebut, perusahaan asuransi tidak dapat melakukan cara pemasaran selain yang telah ditetapkan, dan direct selling bukan merupakan cara pemasaran yang sesuai ketentuan. Secara asas keterbukaan, Otoritas Jasa Keuangan memberikan jawaban terhadap pertanyaan masyarakat melalui e-mail dengan jawaban yang mengarahkan masyarakat terjerumus dalam praktik direct selling yang ilegal.

Tugas dan wewenang Otoritas Jasa Keuangan bertujuan untuk memastikan kesehatan perusahaan asuransi bagi pengaruhnya terhadap perkembangan perekonomian Indonesia. Dalam sadd al-dzariah, pengawasan Otoritas Jasa Keuangan yang lengah merupakan perbuatan yang mengakibatkan perusahaan asuransi menjadi tidak sehat. Cara memasarkan produk 
asuransi dalam memenangkan persaingan antar perusahaan asuransi dilakukan dengan melanggar ketetapan yang berlaku. Kelengahan Otoritas Jasa Keuangan menjadi hal yang tidak boleh terjadi karena menyebabkan bahaya bagi kesehatan perusahaan asuransi.

\section{Pustaka Acuan}

Afrelian, Muhamad Ibnu \& Imahda Khoiri Furqon, Legalitas Dan Otoritas Fatwa Dewan Syariah Nasional Majelis Ulama Indonesia Dalam Operasional Lembaga Keuangan Syariah, Jurnal Ilmiah Mizani, Vol. 6, No. 1, 2019.

Andiko, Toha, Suansar Khatib, Romi Adetio Setiawan. Maqashid Syariah dalam Ekonomi Islam, Yogyakarta: Samudra Biru, 2018.

Andiko, Toha. "Larangan Bercadar di Perguruan Tinggi Perspektif Sadd alDzarî‘ah”, Madania, Vol. 22, No. 1, 2018. Barlinti, Yeni Slam, Kedudukan Fatwa Dewan Syariah Nasional dalam Sistem Hukum Nasional di Indonesia, Jakarta: Badan Litbang dan Diklat Kementerian Agama RI, 2010.

Departemen Agama, Al-Quran dan Terjemah, Jakarta: Yayasan Penyelenggara Penerjemah/Penafsir Al-Quran, 1965.

Djumhana, Muhammad, Hukum Perbankan di Indonesia, Bandung: Citra Aditya Bakti, 2006.

E-mailDirektorat Pelayanan Konsumen Otoritas Jasa Keuangan kepada Anto Cahaya.

E-mail Direktorat Pelayanan Konsumen Otoritas Jasa Keuangan kepada Seri Utami Ningsih.

Fatwa Dewan Syariah Nasional Majelis Ulama Indonesia Nomor 75 Tahun 2009 tentang Pedoman Penjualan Langsung Berjenjang Syariah.

Haryana, Ade, Moral Hazard dalam Asuransi Kesehatan. https://wfdsa.org/about-direct-selling/ https://www.apli.or.id/direct-selling/ https://www.apli.or.id/profil/

Keuangan, Otoritas Jasa, "Penguatan Sektor Industri Keuangan Non Bank melalui Pengaturan yang Berkualitas dan Inovasi Produk \& Jasa Layanan Keuangan”, Kumpulan Karya Tulis Terbaik.

Ningsih, Seri Utami, "Asuransi Berbasis Penjualan Langsung Menurut Hukum Islam dan Hukum Positif (Studi Kasus PT. Asuransi Jiwa Central Asia Raya), Skripsi UIN Sunan Kalijaga Yogyakarta, 2018.

Peraturan Menteri Perdagangan Nomor 32

Tahun 2008 tentang Penyelenggaraan Kegiatan Usaha dengan Sistem Penjualan Langsung.

Peraturan Otoritas Jasa Keuangan Nomor 63 Tahun 2016 tentang Perubahan atas Peraturan Otoritas Jasa Keuangan Nomor 11/POJK.05/2014 tentang Pemeriksaan Langsung Lembaga Jasa Keuangan NonBank.

Sutedi, Andrian, Aspek Hukum Otoritas Jasa Keuangan, Jakarta: Raih Asa Sukses, 2004. Syarifuddin, Amir, Ushul Fiqh 2, Jakarta: Kencana, 2008.

Undang-undang Nomor 21 Tahun 2011 tentang Otoritas Jasa Keuangan.

Undang-undang Republik Indonesia Nomor 15 Tahun 2006 tentang Badan Pemeriksa Keuangan.

Undang-undang Republik Indonesia Nomor 22 Tahun 2004 tentang Komisi Yudisial.

Undang-undang Republik Indonesia Nomor 18 Tahun 2011 tentang Perubahan Atas Undang-undang Nomor 22 Tahun 2004 tentang Komisi Yudisial.

Undang-undang Republik Indonesia Nomor 24 Tahun 2004 tentang Lembaga Penjamin Simpanan.

Zuhaili, Wahbah al-. Al-Wasîth fi Ushîlal-Fiqh al-Islâmi, Damaskus: Dâr al-Kitâb, 1978 